\title{
CURRENT STATE, PROBLEMS AND TRENDS OF DEVELOPMENT OF THE BULGARIAN HOTEL INDUSTRY
}

\author{
SNEJINA KADIEVA
}

\begin{tabular}{l|l} 
& $\begin{array}{l}\text { College of Tourism, University of Economics, Varna, BULGARIA } \\
\text { e-mail: snejinakadieva@gmail.com }\end{array}$ \\
$\begin{array}{l}\text { RECEIVED } \\
\text { ACCEPTED }\end{array}$ & $\begin{array}{l}\text { 1 July } 2016 \\
1 \text { November } 2016\end{array}$ \\
JEL & D47
\end{tabular}

KEYWORDS Bulgarian hotel industry, hotel superstructure, hotel chains in Bulgaria, small family hotel business, Bulgarian hotel product

ABSTRACT The paper examines the development of Bulgarian hospitality industry after the changes in 1989, followed by substantial investment in reconstruction of privatized hotels and the construction of new modern hotel facilities with interesting architecture, exterior and interior design. Based on analysis of statistics, mainly for the period 2008-2015, it outlines the main issues regarding this development, namely, seasonality in the use of the hotel superstructure, low average income of nights spent, excessive construction of big seaside and mountain tourist complexes, relatively low quality of hotel services. It emphasizes the importance of international hotel chains entering the market, their influence on the Bulgarian hotel industry concerning applying best practices and new technology in hotel services. The result being enhanced quality and competitiveness of Bulgarian hospitality industry. The emergence of Bulgarian hotel chains and brands is indicated as a positive trend. The paper addresses the small family hotel business, and its trends of positive development. The advance of small familyowned hotel businesses is an important prerequisite for the development of alternative types of tourism in Bulgaria. The article examines the regulatory framework of categorization of accommodation establishments in the Republic of Bulgaria and the problems that arise in the process of categorization underlining the ineffecient government control over the quality of the hotel product. The strengths and weaknesses of the national hotel product are outlined and possibilities for improving its quality and competitiveness are suggested.

\section{Introduction}

In recent decades the international hotel industry has shown a growing development. A trend that can be outlined currently is an increase in hotel demand and supply. In various destinations supply and demand have been growing at a different pace depending on the phase of the hotel product life cycle. In many destinations supply of hotel products significantly exceeds or has started to exceed demand for hotel services, leading to stagnation in 
the tourism industry, as well as growing competition, especially in its non-price dimensions. The number of hotel chains and their influence is increasing, which have proved more competitive due to the high standards of quality, an established brand name and unified financial and marketing policy. There is a trend towards specialization of the hotel product or a shift from from mass-orientated to individualized markest through product segmentation and differentiation. The trend most strongly manifested is the appearance of theme hotels. The increased requirements of customers in the tourism and hospitality business for environmentally clean surroundings, on the one hand, and overdevelopment of certain tourist areas being targeted at the mass tourist, on the other hand, create an urgent need of respecting the principles of sustainable development. More and more researchers in tourism focus on these problems (Sloan et al., 2013; von Freyberg et al., 2013; Sidorkiewicz, Pawlicz, 2015; Milewski, Pawlicz, Sidorkiewicz, 2010), but unfortunately, the practical results are still unsatisfactory.

The present review paper analyzes the current state, problems and trends of the contemporary hotel industry in Bulgaria against the background of the outlined international trends. A comparative method has been applied for the analysis of collected data and materials.

In its development the modern Bulgarian hotel industry has followed the trends in the development of the international hotel industry. After the changes of November 10, 1989, the process of privatization of the hotel facilities started and this process ended in the mid-90s of the $20^{\text {th }}$ century. Since that period the reconstruction and modernization of privatized hotels and building of new ones has began. The increased interest of local and foreign investors has led to a trend of rapid growth in the number of accommodation establishments and the number of beds in them. According to data from Bulgarian National Bank (BNB) (www.bnb.bg) in 2009, when construction of hotel facilities was very intense, the amount of foreign direct investment in tourism and hospitality reached 561 million Euros, which is $25 \%$ of total foreign direct investment in Bulgaria. According to the National Statistical Institute (NSI) in Bulgaria (www.nsi.bg) the number of accommodation establishments has risen from 1,250 in 1990 to 3,202 in 2015. (an increase of approximately 40\%). In 2015 the number of beds available, according to official statistics, has reached 322,465 beds, which shows an increase of over $100 \%$ compared to the year 2000 . For the period 2008-2015 the number of beds in accommodation establishments increased by $117 \%$, this growth was achieved despite the global economic crisis (see Table 1).

Table 1. Statistical data on hotel industry in Bulgaria (2008-2015)

\begin{tabular}{|c|c|c|c|c|c|c|c|c|c|}
\hline Year & $\begin{array}{l}\text { No of acco } \\
\text { mmoda } \\
\text { tion estab } \\
\text { lishments- }\end{array}$ & $\begin{array}{c}\text { Noof beds } \\
\text { available }\end{array}$ & $\begin{array}{c}\text { No of } \\
\text { bednights } \\
\text { (in thousand) }\end{array}$ & $\begin{array}{c}\text { Total No of } \\
\text { nights spent } \\
\text { (in thousands) }\end{array}$ & $\begin{array}{l}\text { No of nights } \\
\text { spent by } \\
\text { foreigners only } \\
\text { (inthousands) }\end{array}$ & $\begin{array}{l}\text { No of nights } \\
\text { spent by } \\
\text { Bulgarians (in } \\
\text { thousands) }\end{array}$ & $\begin{array}{c}\text { Average } \\
\text { annual } \\
\text { occupan-cy } \\
\text { rates (in \%) }\end{array}$ & $\begin{array}{l}\text { Revenue on } \\
\text { nights spent } \\
\text { (in thousands) }\end{array}$ & $\begin{array}{l}\text { Average } \\
\text { revenue per } \\
\text { nights stay } \\
\text { (in levs) }\end{array}$ \\
\hline 2008 & 3,217 & 276,586 & 60,765 & 18,294 & 11,802 & 6,493 & 30.8 & 740,999 & 40.50 \\
\hline 2009 & 3,533 & 287,423 & 61,801 & 15,372 & 9,472 & 5,900 & 24.9 & 626,492 & 40.80 \\
\hline 2010 & 3,540 & 283,641 & 57,564 & 16,261 & 10,565 & 5,992 & 27.0 & 653,737 & 34.70 \\
\hline 2011 & 3,776 & 283,251 & 58,855 & 18,855 & 12,461 & 6,394 & 32.0 & 733,053 & 38.90 \\
\hline 2012 & 2,758 & 301,140 & 56,211 & 20,252 & 13,451 & 6,801 & 36.0 & 836,210 & 41.30 \\
\hline 2013 & 2,595 & 302,433 & 58,740 & 21,617 & 14,370 & 7,247 & 36.8 & 919,831 & 42.50 \\
\hline 2014 & 3,163 & 314,257 & 61,396 & 21,698 & 14,078 & 7,620 & 35.34 & 998,345 & 46.00 \\
\hline 2015 & 3,202 & 322,465 & 62,394 & 21,398 & 13,352 & 8,046 & 34.29 & 1,033528 & 48.30 \\
\hline
\end{tabular}

Source: composed by the author according to NSI data: http://www.nsi.bg/bg/content (2008-2015). 
As shown in Table 1, the average annual occupancy rate of accommodation facilities in the Republic of Bulgaria for the period (2008-2015) varies between $30 \%$ and $36 \%$ and can be eastimated as low. In comparison, it should be noted that the region of Europe in 2014 had the highest average annual occupancy rate of its hotel facilities $-68.8 \%$. (www.statista.com)

Low is the average revenue from an overnight stay for the period 2008-2015 - between 40-48 Levs, and in 2010, during the economic crisis, it fell to 34.07 Iv. Considering the above indicators it can be concluded that the hotel facilities are not used efficiently, the majority of hotel business is seasonal, which, in turn, makes return on investment in Bulgarian hospitality industry more difficult. Here we should note the fact that in $201469.8 \%$ of the beds were in 3, 4 and 5-star accommodation establishments. So sales at higher prices and higher average income from an overnight stay were supposed to be generated. The reasons for the low average income of an overnight stay, despite the relatively high proportion of high category hotels are: the image and the market position of Bulgaria on the international tourism market primarily as a cheap tourist destination. The distribution of the Bulgarian hotel product for holiday recreation is done mainly through foreign tour operators by the formula "all inclusive", who negotiate significant discounts for pre- and post-season in our seaside and mountain resorts. Table 2 presents the average stay in days of 1 tourist in a hotel, which is between 3.50 to 3.68 days. Efforts should be made to extend the average length of stay in a hotel. This can be achieved by attractive offers and leisure packages to stimulate consumption and longer stays in hotels.

Table 2. Statistics of number of nights spent, arrivals and average stay of a tourist in accommodation establishments in Bulgaria (2008-2015)

\begin{tabular}{|c|c|c|c|c|c|c|}
\hline Year & $\begin{array}{c}\text { No of total nights } \\
\text { spent } \\
\text { (in thousands) }\end{array}$ & $\begin{array}{l}\text { No of total nights } \\
\text { spent - foreign } \\
\text { tourists } \\
\text { (in thousands) }\end{array}$ & $\begin{array}{l}\text { No of arrivals in } \\
\text { accommodation } \\
\text { establishments - } \\
\text { (in thousands) }\end{array}$ & $\begin{array}{l}\text { No of arrivals in } \\
\text { accommodation } \\
\text { establishments - } \\
\text { foreigners only } \\
\text { (in thousands) }\end{array}$ & $\begin{array}{l}\text { Average stay } \\
\text { per one tourist } \\
\text { (in days) }\end{array}$ & $\begin{array}{c}\text { Average stay } \\
\text { per one foreign } \\
\text { tourist } \\
\text { (in days) }\end{array}$ \\
\hline 2008 & 18,294 & 11,802 & 5,025 & 2,226 & 3.64 & 5.31 \\
\hline 2009 & 15,372 & 9,472 & 4,391 & 1,948 & 3.50 & 5.13 \\
\hline 2010 & 16,261 & 10,565 & 4,412 & 2,084 & 3.68 & 5.06 \\
\hline 2011 & 18,855 & 12,461 & 5,045 & 2,423 & 3.73 & 5.14 \\
\hline 2012 & 20,252 & 13,451 & 5,494 & 2,632 & 3.67 & 5.11 \\
\hline 2013 & 21,617 & 14,370 & 5,837 & 2,819 & 3.70 & 5.10 \\
\hline 2014 & 21,698 & 14,078 & 5,946 & 2,792 & 3.65 & 5.04 \\
\hline 2015 & 21,398 & 13,352 & 6,279 & 2,864 & 3.41 & 4.66 \\
\hline
\end{tabular}

Source: composed by the author according to NSI data: http://www.nsi.bg/bg/content (2008-2015).

The hotel superstructure comprises the physical facilities for the provision of hotel services. The content of the hotel superstructure is reflected in the different accommodation establishments - hotels, villas, guest houses, campsites, etc., which are characterized by great diversity. Quantitatively the hotel superstructure is expressed by the number of beds in the accommodation establishments (Dabeva, 2013). Investments in the hotel superstructure in Bulgaria were focused mainly to the seaside resorts - Slanchev Bryag, Golden Sands, Riviera and in the mountain resorts: Bansko, Borovets and Pamporovo. Parallel with them a number of spa resorts were modernized in the towns of Velingrad, Devin, Hissar, Sandanski and others. In our four major spa destinations in Bulgaria - 
Velingrad, Devin, Sandanski and Hissar there is a total of 52 hotels with mineral water with a total bed capacity of 4,841 beds. (www.hotel359.com). According to the Bulgarian Union of Balneology and SPA tourism in the last 10 years Bulgaria has invested over 1 billion Euros in the spa industry (www. econ.bg/Новини). In the larger cities Sofia, Plovdiv, Varna, Rousse, many city and business hotels were built, a number of which are within international hotel chains - Hilton, Sheraton, Holiday Inn, Best Western, RadissonBlu, Ibis, Novotel Sofia, Kempinski-Grand Arena Bansko, Ramada, etc. In the field of holiday recreation we have also observed the rise of international hotel chains like - RIU, Sol Melia, Iberostar, Prima Sol, Barcelo, Calimera, LTI, Sentido and others. The operation of international hotel chains in Bulgarian hotel industry helped transfer best practices and technological experience in hotel services, and in this way enhance the quality and competitiveness of the Bulgarian hospitality industry. According to Euromonitor data in 2013 only 31 hotels in Bulgaria were part of international hotel chains, which is $2 \%$ of the hotel facilities. However, they generate much higher average annual sales of hotel unit, 2.3 million levs, than independent hotels $-828,000$ lv of hotel unit. (www.euromonitor.com /passport travel accommodation in Bulgaria/ august 2013). The creation of Bulgarian hotel chains and brands can be pointed out as a positive trend. In 2015 there were 18 hotels and a total of 80 hotel complexes involved in them. (Ivanov, Ivanova, 2015). These are the hotel chains: Sharlopovhotels, Victoria Group, Grifidhotels, Festa Hotels, Lion, E Hotels, FairplayProperties, Acquahotels, MPM Hotels, Imperial Hotels Group, HVD Hotels and others. Up to 1.05.2015 the number of hotels included in chains in Bulgaria (Bulgarian and foreign) were 132 or $4.17 \%$ of all hotels in the country. In comparison "the group of chain component of the hotel sector accounts for a rise of $10 \%$ of propety stock in most European coutries" (Fletcher, Fyall, Gilbert, Wanhill, 2013).

There is a massive concentration of hotel establishments in and around the large and established seaside and mountain resorts, which leads to a problem of overconstruction. As a result, about $47 \%$ of the beds in the country are located in our bigger seaside and mountain resorts (www.nsi.bg/otrasal). Revenues from nights spent for the whole country during the months of June, July and August (active summer season of 2012) were 727,503,000 in levs, which represents $60 \%$ of revenues from nights spent in the whole country, and it shows the strong seasonality of the hotel business.

Alongside with investing in large-capacity hotels owned by big business in Bulgaria and abroad, in the late $80 \mathrm{~s}$ and early $90 \mathrm{~s}$ of the $20^{\text {th }}$ century the development of small family hotel business was started. The family hotel businessis is an important factor for the development of alternative types of tourism in Bulgaria such as rural tourism, eco tourism, health, sports, culture, hiking, etc. The advantage of family hotel business is associated with increasing the elasticity of the tourism offer in seasonal concentration of demand in peak periods, as well as generating additional revenue for the local population and it partly helps overcome unemployment. According to the official register of the categorized tourist sites by Mayors of Municipalities (www.mi.government.bg) in Bulgaria officially registrated and categorized are family-owned accommodation establishments (family hotels, boarding houses, guest houses) are more than 4,000. As it is clear from the data, the number of sites representing small businesses in the hospitality industry, including family hotels in Bulgaria, is significant and their product positioning on Bulgarian and international markets enhance their competitiveness. The majority of these family hotels have good facilities. The buildings were designed in interesting and original architectural styles. They maintain good hygiene and safety and security of customers is ensured. The prices at which that type of small family hotels are sold are affordable and reasonable for the mass clientele. The main problems related to the quality of "family hotels" product in our country are: unsatisfactory condition of general engineering infrastructure, lack of professionalism 
in service due to low professional and language qualifications of the staff, the seasonality issue for most of hotels, which in turn leads to the inability to provide year-round staff and to maintain a sustainable level of quality. As a result of all of this, it is difficult for the small family hotel business to achieve profit margin enabling better return on invested funds and the desired efficiency.

Legislative regulation of the hospitality industry in Bulgaria is performed by the existing Tourism Act, passed by Parliament on 26.03.2013, with recent amendments in 2015 (www.tourism.government.bg). Chapter Four, Section Three of this Act regulates the conditions and procedures for the two main tourism activities - hotel and restaurant business. In Bulgaria there is a government regulation on the requirements for accommodation and catering establishments and on procedures of identifying the category, denial, reduction, suspension and termination of the category. It was adopted by Council of Ministers Decree № 217 of 17/08/2015, promulgated in the Government Gazette. No. 65 from 25 August 2015. According to the Regulation, the rating system is compulsory for all of the accommodation establishments in Bulgaria, regardless of form of ownership. Exceptions are only mountain chalets that are classified in categories one to three Edelweisses, according to a separate regulation for categorization. The recommended five-star rating system of the World Tourism Organization has been adopted. The accommodation establishments, according to the Ordinance for classification are divided into two groups. Accommodation establishments Class "A" - hotels, motels, apartment hotel complexes, holiday villages, tourist villages and villas. Accommodation establishments Class "B" includes family hotels, hostels, boarding houses (B\&B), holiday homes, guest houses, guest rooms, guest apartments, bungalows and camping sites. Along with the advantages of the mandatory state regulation categorization of accommodations in Bulgaria determining basic parameters of the hotel product, there are some shortcomings, which need to be outlined. In the National Ordinance it is not terminologically explained and there are no standards provided for boutique hotels, condominium hotels, budget hotels and others, which are representatives of alternative accommodation and are becoming more widely used in the international hospitality business, including Bulgaria. Theere is a lack of strict control mechanism in compliance with the requirements of the ordinance regarding already categorized accommodation. In some ways the Ordinance for categorization is contrary to the standards and specifications of international hotel chains operating in Bulgaria. Along with the Ordinance for categorization in Bulgarian hospitality it is appropriate to establish voluntary national and regional systems of certification and awarding brands for quality.

The characteristics of the Bulgarian hotel product may be summarized in the following areas: It valorizes attractive natural and anthropogenic resources in Bulgaria, but not in line with their carrying capacity, despite of the state of law in the country on their conservation. This has led to overdevelopment of some areas, destroying valuable resources and oversaturation of the existing capacity. As a superstructure the hotel product features modern hotel buildings with interesting architecture, exterior and interior design. A large share of premium class hotel superstructure (4-5 stars), which is $38 \%$ of the beds in Bulgaria, does not match the profile of tourists visiting destination "Bulgaria". Poorly developed engineering and transport infrastructure, which does not comply with the capacity and characteristics of the superstructure and has lead to deterioration of the quality of the hotel product. Better parameters of the technical aspects of the quality of hotel product have been achieved - modern construction technologies, advanced equipment with energy-saving machines and equipment, implementation of modern information technology and software development products, facilities for leisure and recreation. Unsatisfactory parameters of the functional aspects of quality - imperfect organization and operations technology of hotel service, lack of cozy unique atmosphere in hotels, insufficient empathy and responsiveness of staff to the 
guests, the absence of a personalized approach to hotel guests. Problems with recruitment of qualified staff due to seasonality and low pay offered. Limited application of systems of quality management in the hospitality companies in Bulgaria, created to internationally recognized standards. Only 14 hotel companies in Bulgaria are certified in accordance with the international quality standard ISO 9001. Insufficient application of the principles of sustainable development and corporate social responsibility. Only one travel agency is certified according to the international standard for environmental protection, ISO 14001. 28 guest houses in Bulgaria are awardes the sign "Green House". "Green House" is a certificate that evaluates Bulgarian guesthouses and family hotels in terms of environmental protection in the international guidelines of the European Association for Rural Tourism "Eurogites".

Strategies for the future development of the hospitality industry in Bulgaria should focus on joined efforts of public, private and voluntary sectors to overcome the weaknesses of the hotel product outlined above in order to achieve its high competitiveness. According to the the Travel \& Tourism Competitiveness Report, published by the World Economic Forum for 2015, Bulgaria occupies $49^{\text {th }}$ place in the ranking of the competitiveness of the tourism industries of 141 countries in the world with an index of competitiveness of the travel and tourismsector 4.05 measured in values from 1 to 7 (The Travel \& Tourism Competitiveness Report, 2015).

\section{Conclusions}

The hotel industry in Bulgaria is developing in line with the international trends in the hotel industry as a whole. There is an increase in investment in the hotel superstructure, increase in the number of specialized hotels - for mountain, sea tourism, spa - and wellness tourism. There is substantial growth of small family-owned hotels. Problems that have not yet been overcome are: the negative processes of seasonality in the majority of Bulgarian hotels, a relatively low average revenue per 1 tourist, low average revenue per nights stay and average stay of a tourist in the hotel. Better targeted tourism policy should be implemented, including at "destination" level, which can help diversify the hotel product and improve its distribution. Bulgarian hoteliers should be involved in the certified systems of quality management to ensure customer satisfaction and quality of service. Bulgarian hotels should put greater effort in applying the principles of sustainable development and corporate social responsibility aiming to increase the competitiveness of Bulgaria as a tourist destination.

\section{References}

Dabeva, T. (2013). Hotelierski i restorantyorski franchaysing. Varna: Nauka i Ikonomika.

Fletcher, J., Fyall, A., Gilbert, D. \& Wanhill, St. (2013). Tourism: Principles and Practice. Pearson Education Limited, Fith Edition.

Freyberg von, B., Gruner, A. \& Hübschmann, M. (2014). Nachhaltigkeit als Erfolgsfaktor in Hotellerie \& Gastronomie: Ein Praxisbuch für Hotellerie und Gastronomie Gebundene. Mattheas Verlag.

http://ep00.epimg.net/descargables/2015/05/06/f2c1e517ce56a6453171d3a9d1b1da05.pdf, p. 112 (12.03.2016).

http://www.bnb.bg/ResearchAndPublications/PubResearch/PubRResearch/index.htm (15.11.2015).

http://www.mi.government.bg/bg/themes/registar-na-kategoriziranite-turisticheskiobekti-ot-kmetovete-na-obshtini-623-397.html (21.08.2013).

http://www.nsi.bg/bg/content (2008-2015).

http://www.nsi.bg/otrasal (12.12. 2015).

http://www.statista.com/statistics/247264/total-revenue-of-the-global-hotel industry (21.11.2015).

Ivanov, St. \& Ivanova, M. (2015). Available at: http://www.slideshare.net/stanislavhivanov/travel-academy-presentation (22.11.2015). 
Milewski, D., Pawlicz, A., \& Sidorkiewicz, M. (2010). Oferta hotelarska w miejscach kultu religijnego w Polsce na przykładzie domów pielgrzyma. In: Z. Kroplewski, A. Panasiuk (eds.), Turystyka religijna. Szczecin: Wydawnictwo Naukowe Uniwersytetu Szczecińskiego.

Sidorkiewicz, M., \& Pawlicz, A. (2015). Propedeutyka hotelarstwa. Ujęcie ekonomiczne. Warszawa: Difin.

Sloan, Ph., Legrand, W. \& Chen, J. (2013). Sustainability in the Hospitality Industry 2nd Ed: Principles of Sustainable Operations. Routledge.

The Travel \& Tourism Competitiveness Report (2015).

www. econ.bg/Новини (29.05. 2014).

www.euromonitor.com /passport travel accommodation in Bulgaria (August 2013).

www.hotel359.com (7.02.2016).

www.tourism.government.bg/sites/tourism.government.bg/files/documents/201503/zakon_za_turizma_izm_2015_mt.pdf (20.01.2016).

Cite this anticle aS: Kadieva, S. (2016). Current state, problems and trends of development of the Bulgarian hotel industry. European Journal of Service Management, 20 (4), 25-31. DOI: 10.18276/ejsm.2016.20-03. 
